\title{
Investigating the Influence of Distributed Leadership on School Effectiveness: A Mediating Role of Teachers' Commitment
}

\author{
Hairuddin Mohd Ali \\ International Islamic University Malaysia (IIUM), \\ hairuddin@iab.edu.my, hairuddin@iium.edu.my \\ Salisu Abba Yangaiya \\ Department of Educational Foundation, Isa Kaita College of Education Dutsinma, Katsina State, Nigeria \\ yangaiya@yahoo.com, yangaiya1965@gmail.com
}

\section{Doi:10.5901/jesr.2015.v5n1s1p163}

\section{Abstract}

The purpose of this study is to investigate the influence of distributed leadership (DL) on school effectiveness (SE) in junior secondary schools in Katsina state, Nigeria. The study also investigates if teachers' commitment (TC) mediates the relationship between DL and SE. The study sampled three hundred and one (301) teachers. SPSS version (16.0) and Analysis of Moment Structure (AMOS) version (16.0) were used to analyze the data collected. The results indicated that there is a statistically significant relationship between DL and SE (with standardized coefficient .68). In addition, TC influences SE (with standardized coefficient 0.38). Moreover, TC mediates the relationship between DL and SE (standardized coefficient 0.22). The implication of the study is that all stake holders; head teachers, zonal office staff, ministry officials among others are now better informed about the mediating role of TC on DL and SE. The results contributes to the existing body of knowledge in Nigeria. Very few studies investigate the relationship between DL and SE, in Katsina state in particular, and Nigeria in general.

Keywords: Distributed leadership, School effectiveness, Teachers' commitment, Structural Equation Modeling.

\section{Introduction}

No matter from whose and from what perspective, what so called a "leader" was dominantly and gloriously enriching the leadership literature for centuries. From Western perspective however, Daft (1999) argues the need and significance of a strong, purposeful and dynamic leadership in any organizations due to its ability to influence the success and or failure of any organization (Yukl, 2002; Lok \& Crawford 2004; Megginson et al., 1983 \& Lunenburg, 1995). As from another conception of leaders and leadership, Islamic observes and stresses the importance of appointing a leader "When three

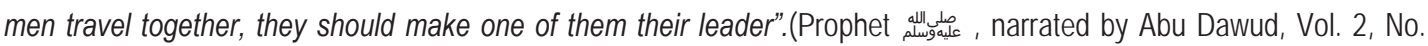
2273 on the authority of Abu Sa'id Al-Khudri). And about the importance of appointing competence leaders, the Prophet alle further says, "Whoever delegates a position to someone whereas he sees someone else as more competent (for the position), verily he has cheated Allah and His Apostle and all the Muslims". (cited in Sahih Muslim, Vol. 3, No. 1013).

Leadership has also long been seen as a key factor in organizational effectiveness, but the interest in educational leadership area has increased over the recent decades due to the political changes to the education system such as the growth of school-based management in many countries (Mujis, 2011). Regrettably, when new leadership theories have been formulated, it was then packaged and successfully sold to schools without adequate scrutiny or testing (Harris, 2008a) resulting in too many "war stories" of educational leadership. Moos, Krejsler, Kofod and Jensen (2005) note that leadership in a school setting moves among the principal, deputy or vice principals, head of departments, head of sections, teachers as well as students, and this set up makes a school a community where the interactions and reciprocity of all members thrived on. Leithwood et al. (2004) note that instances can be cited of school facing some challenges being reformed with the support of a good, knowledgeable and effective leader. They further argues that there may be some factors that may help in the transformation, but nonetheless, the leader is the most important. In addition, Pont, Nusche, and Moormen (2008) note that in each individual school, leadership can contribute to the improvement of students by providing the conditions as well as climate in which effective teaching and learning can 
thrive. It has been established that apart from classroom teaching, there is hardly anything that positively or negatively affects students' learning than leadership. Besides, Storey (2004) argues that irrespective of the problems schools face their solutions rested squarely with leadership.

Previously, the responsibility of moving an organization towards its realization of aims and objectives rest squarely on the "solo", "focused" or "heroic" leader. But, of recent there has been a challenge to the ability of a single leader to successfully run an organization (Oduro 2004, Ross \& Gold 2005). This challenge is more pronounced in school setting, as a result of the rise in demand for educations, parents' expectations, government policies, and principals' turnover to mention just few. In addition, Nieman and Kotze (2006) argue that the presence of ineffective schools clearly indicates the need towards making school leadership effective is long overdue and the culture that improves effective teaching and learning in those schools need to reviewed. Precisely, there is a need to critically review the ways all schools are being run in realizing their objectives of effective teaching and learning. Moreover, critical areas that need to be reformed in order to enhance effective teaching and learning in schools can no longer be handled single handedly by the head teacher (Spillane 2006, Harris 2008a). It has been argued that student's outcomes are more likely to improve if leadership is distributed in school and teachers collective decisions related to teaching are taken into consideration (Silins \& Mulford 2002).

Leadership is also means an interaction of all members of the organization for the purpose of promoting the shared purpose or set of goals that should be pursued and realized for the organization to achieved its objectives (Harris, Day, Hopkins, Hadfield, Hargreaves \& Chapman, 2005). Robbinson (2008) equally notes that leadership means leaders' influence on organizational members which is linked to goals and objectives of the organization. Gronn (1999, 2000, 2002a, 2002b \& 2008) stresses that there has been increasing dissatisfaction and disagreement with the domination of a single or solo (hero?) leader in most of the leadership literature, but very little rigorous studies on leadership alternatives were conducted in those days. However, time has changed whereby more studies on the alternatives of solo or focused leadership have cropped up and more studies are beginning to support the role of distributed as opposed to solo leadership in term of performance (lles \& Feng, 2011). Distributed leadership (DL) as an alternative to the solo or focused leadership is considered leaning towards the importance of the leadership-followership relationships where the literature observes the 80:20 ratio of the followers contribution towards the organizational success (Kelly, 1992). But, we cannot deny that every great leaders is also a great follower (Bailey, 2013).

\section{Leadership Types that Affect Educational Outcomes}

We accept every argument and criticism over the results of the relationship between leadership and student achievement and outcome, but please let this article to highlight some of the leadership effects on educational outcomes. Mujis (2011) lays his claim that the leadership literature tends to be quite prescriptive in nature, and factors such as transformational rather than transactional leadership, instructional rather than administrative leadership, and leadership rather than management have all been posited as key elements of organizational effectiveness. Transformational leadership (TL) is usually described as leadership that transforms individuals and organizations through an appeal to values and long term goals. This popular leadership is engaged with hearts and minds, and it is therefore popular in education sector as it is seen as better able to cope with complex situations and together with instructional leadership found to be a characteristic of effective leaders (Hallinger \& Heck, 1996, 1998, \& 2010) and hence providing some evidence in the literature that TL has positive organizational impacts. Further, Mujis (2011) argues that, although transformational leaders are considered successful, difficulties arise when this "heroic" person leaves the organization or when not all followers get inspired, leading to problems being stored up for the future.

Instructional leadership (IL) is also identified as a key component of effective schools (Teddlie \& Reynolds, 2000). Hallinger and Heck (1996, 1998 \& 2010) coin IL as being concerned with hands-on involvement with teaching and learning processes where the principal plays his leadership roles as leader with regard to pedagogy and instruction to promote growth in student learning and making instructional quality the top priority of the school and brings the vision to realization. Mujis (2011) stresses that, in many cases instructional leaders start the school improvement process by implementing a particular initiative promoting a teaching strategy. The relationship between IL and educational outcomes is quite long established where Heck et al. (1990) found an indirect relationship between three latent variables and principal IL such as school governance, instructional organization and school climate affected student achievement. This evidence is still true and accepted until Hallinger (2011) reviewed it 15 years later. However, as stresses by Mujis (2011), we can question the extent to which IL is still feasible due to the quests of principals taking on new roles currently.

The weaknesses of traditional views of TL and IL have enticed many researchers and practitioners to advocate 
distributed forms of leadership involving all staff levels in leading their organization and this definitely contradicts the views that TL in particular can reside in all members of an organization (Mujis, 2011). This is why, increasingly, researchers and policymakers have called for a move towards a more distributed forms of leadership, that is distributed leadership (DL). Distributed leadership indicates that the practice of leadership is stretched within and across the organization and there are high degrees of involvement of all staff in the practice of leadership (Spillane et at., 2001). Due to this, Gronn (2000) identifies DL as an emergent property of a group or network of individuals in which group members pool their expertise. Fletcher and Kaufer (2003) affirmed that DL is enacted by people at all levels rather than a set of personal characteristics and attributes located in people at the top. It is a form of leadership practice where individuals collaborate in order to extend and enhance the leadership capacity within or across organizations.

\section{Distributed Leadership (DL) as an Alternative Factor for Student Outcomes and School Effectiveness}

Gronn (2002), Burke et al. (2003), Manz and Sims (1990, 1991 \& 1993) claimed that the recent interest in the field of DL has to some degree been fueled by its association with certain organizational benefits. Other than that, the lacking of other forms of leadership in solving effectively the ever increasing challenges facing in educational organizations, paved the way for the emergence of leadership practice alternatives known as stretched, dispersed, shared and or DL. Furthermore, it has been argued that the future of school leadership as its presently formed does not look good, consequently, the need for entirely different approach to leadership practice cannot be over emphasized, considering the challenges the schools in different parts of the world are facing (Harris 2008b). The most contemporary interpretation of DL theory was contributed by Spillane (2006). DL is a post- heroic leadership model, where the organizational activities are shared among organizational members (Hulpia, Devos \& Keer, 2010). Oduro (2004) argues that post-heroic leadership encourages teamwork, participation, empowerment, risk-taking and de-emphasized control over others. Ross et al. (2005) look at DL as a collective effort of members of the organization whereby leadership is the responsibility of all members of the organization, not necessarily restricted to those with leadership and managerial position, In addition, Harris (2008b) looks at DL as any form of stretched, collaborative or dispersed leadership practice in schools. According to Heck and Hallinger (2011) DL can be viewed as collaboration practiced by the head teacher, teachers and other members of the school's improvement team for the purpose of improving the school in terms of effective teaching and leaning.

Unfortunately, Robinson (2008) stresses that the studies on DL has not been tightly focused on students outcomes where she claims that about one thousand published studies of educational leadership, less than 30 have empirically tested the relationship between leadership and student academic outcomes. What worries the educational leadership fraternity is in fact due to the National College of School Leadership (NCSL) report that there are no empirical data on effectiveness of DL in terms of pupil or student achievement (Bennet et al., 2003 \& Hartley, 2007). This statement contradicts to Southworth and Doughty's (2006) assertion that three decades of school effectiveness and school improvement research across the world have shown that leadership matters. It is also contradicted to Mujis (2011) where leadership has a significant indirect impact on student outcomes although he also argued that the research base suffers from significant weaknesses such as dualism, over-prescribed, lack of international research, limited methodologies plus poor measurement. Silins and Mulford (2002) who comprehensively studied the leadership effects on student learning, concluded that student outcomes are more likely to improve when leadership sources are distributed throughout the school community and when the teachers are empowered in areas of importance to them. As a result Harris (2005) and Camburn et al. (2003) and other scholars appealed for more investigation of DL impact on student outcomes.

Harris et al. (2007), Harris (2008a,b) stress that DL cannot be accepted at face value due to critical questions which require serious empirical research. Distributed leadership is beyond a single talented and influential leader who changes an organization, it is a stage where the leadership is stretched and shared to most organizational members for the betterment of the organization (Angelle 2010). According to Spillane (2006) distributed leadership provides another way of looking at leadership in schools, by emphasizing the aspect of leadership practice and assuming that leadership practice is the product of interactions between leaders, followers and situations. While there is some evidence of showing a positive relationship between distributed forms of leadership and learning out comes (Mujis \& Harris, 2003; Hallinger \& Heck, 1996, 1998 \& 2010), this evidence base is still emerging (Leithwood et al. 2006a, 2006b \& Harris, 2008a,b). A range of other studies such as Portin (1998) and Blasé and Blasé (1999) also found positive relationship between organizational change and distributed forms of $\mathrm{DL}$ practice. These research consistently underline the importance and significance of teachers involvement in decision making- process and the contribution of collegial relationship to positive school improvement and change. 
In educational setting, school effectiveness studies started off in the early 1970s as an important and excellent movement to go beyond the existing pessimism with regard to the impact of schools and education on students' educational achievement and or performance (Mujis, 2006). School effectiveness can be viewed as the place of a school academically, which is usually explained in terms of output of the school. Furthermore, the output is mostly expressed in terms of average academic achievements of the students in that school at the end of certain period of their formal schooling (Scheerens, 2000). OCPS (n.d) argues that school effectiveness has seven dimensions particularly safe and orderly environment, climate of high expectations for success, instructional leadership, opportunity to learn and student time to task, clear and focused mission, frequent monitoring of students progress, and last but not the least home-schoolrelation.

There are a number of factors that influence the school effectiveness including environment, teacher empowerment, to mention just few. However, it has been argued that the most critical and important factor that influences school effectiveness is leadership practices. According to Huber and Mujis (2010), leadership has since been identified as a critical and important factor that influences organizational effectiveness. In addition Leithwood et al. (2006) opines that it's an undisputable fact that educational leadership makes a difference in enhancing students' learning.

Notwithstanding the arguments advanced by scholars regarding the influences of distributed leadership on teachers and school effectiveness, empirical studies regarding the influence is scarce (Harris et al. 2007). However, the studies available indicate that distributed leadership directly and indirectly influences school effectiveness. Mascall et al. (2008) in their study on distributed leadership and teachers academic optimism which in turn affects school performance found that planned approach to distributed leadership positively and significantly influences teachers' academic optimism which in turn affects school performance. Additionally, Heck and Hallinger (2011) in their study on distributed leadership and school improvement and growth in Math achievement found that schools where teachers perceived that leadership is distributed appeared better able to enhance their academic capacity. Similarly, in her study on distributed leadership and students' achievement Angelle (2010) found that there is distal link between distributed leadership and increase students achievement. Moreover, the study found that organizational outcome like; job satisfaction, teacher efficacy, among others increase in a school where leadership is distributed. Salfi (2011) in his study found that $76 \%$ of principals in successful schools encourage distribution of leadership and work with and through other staff in order to improve their schools.

There are at least two studies that tried to explore the relationships between DL and student outcomes, one was by Leithwood et al. (2006b) and the other is by Silins and Mulford (2002). Leithwood et al. concluded that distributing a larger proportion of leadership activity to teachers has a positive influence on teacher effectiveness and student engagement. They also agreed that the teacher leadership has significant effect on student engagement and far outweighs the principal leadership effects after taking into account home and family background. Particularly in Australia, Sillins and Mulford found cumulative confirmation of distributed kind of leadership influence student learning outcomes. Similarly, a study by Harris and Mujis (2004) also found the positive relationship between the degree of teachers involvement in decision making and student motivation and self-efficacy. The findings also reveal that the effects and impacts of DL on organizational outcomes depends upon the pattern of leadership distribution such as spontaneous collaboration, intuitive working relations, institutionalized practice (Gronn, 2002), planful alignment, spontaneous alignment and anarchic alignment (Leithwood et al., 2007). Although we tried our very best to claim the significant positive effects of DL on student achievement and organizational change but we have to admit that $\mathrm{DL}$ is not a panacea or a "one size fits" all forms of leadership practice (Fletcher \& Kaufer, 2003). Spillane (2006) and Fullan (2001 \& 2007) asserts that $\mathrm{DL}$ is one potential contributor to positive change and transformation in schools and educational system.

This articles explores, mainly the evidence of relationship between DL and school effectiveness (SE). In addition, this article also explores if teachers' commitment (TC) mediates the relationship between DL and SE. It is hoped that alternative models of lateral and DL which are now promoted as ways to harness the energy, will motivate the professional learning of teachers and school leaders in securing sustainable innovation and improvement (Hargreaves \& Fink, 2008).

\section{Teachers' Commitment (TC) and School Effectiveness (SE).}

In general, organizational commitment means, organizational members wish to be active players in that organization, have an influence on what is happening in it, feel that their standing in that organization is high and are ready to put in their best effort beyond what is expected of them (Bogler \& Somech, 2004). Mowday, Steers and Porter (1979) looked at commitment as the relative strength of an individual's identification with and involvement in a particular organization while 
Meyer and Allen (1991) proposed that organizational commitment is categorized into three components particularly, affective commitment, continuance commitment and normative commitment.

Razak et al. (2009), stressed that quality education just cannot be realized without the effort and contribution of dedicated and committed teachers. Additionally, Graham (1996) argues that teachers' commitment is an important factor that influences effective teaching and learning in schools. According to Razak et al. (2010) teacher commitment is believed to be an important factor that affect positively on school effectiveness and the success of education system. According to Eginli (2009) committed teachers who have the support of their colleagues and leaders experience the fulfillment of their professional work as a result of their ability to reach every student. Eginli, further noted that committed teachers may likely to stay in the profession and continue to have positive impacts on students' achievement.

In their study on commitment and effectiveness Wiener and Verdi (1980) found that job commitment was strongly related with indices of effort and performance effectiveness. Furthermore, Suliman (2002) in his study on mediating role of commitment on work relation and performance found that organizational commitment mediates the relationship between work climate and performance. In another scenario, Sezgin (2009) found that psychological hardiness is significantly and positively associated with identification and internalization dimensions of teacher commitment.

Figure 1 exhibits the hypothesized model of the study where it is hypothesized that there is a statistically direct significant relationship between DL and SE, a statistically direct significant relationship between TC and SE. Lastly, TC is statistically mediating the relationship between DL and SE. Hence, based on the hypothesized model of the study, the following research hypotheses are presented for testing:

H1. There is a statistically direct significant relationship between distributed leadership (DL) and school effectiveness (SE).

H2. There is a statistically direct significant relationship between teachers' commitment (TC) and school effectiveness (SE).

H3. Teachers' commitment (TC) mediates the relationship between distributed leadership (DL) and school effectiveness (SE).

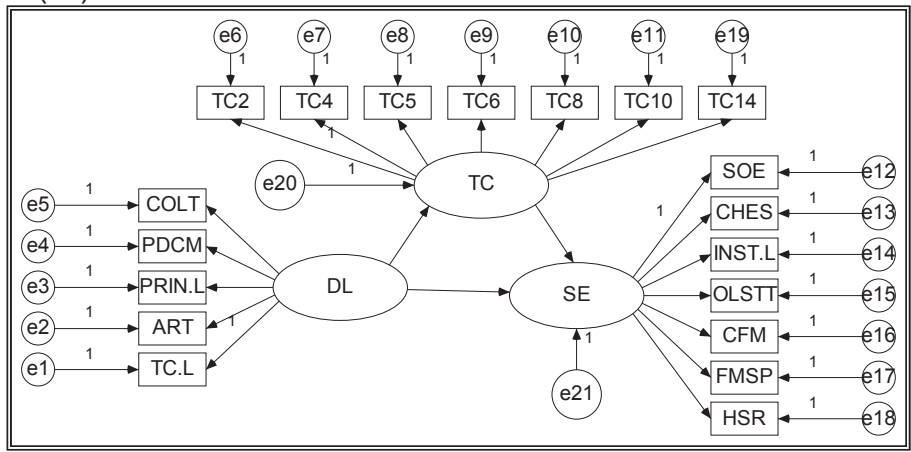

Figure 1. The Hypothesized Model of Study

\section{Methodology}

\subsection{Quantitative approach}

The study employed survey method to get the needed information from the sample of the study. McMillan (1992) and Hutchinson (2004) argue that information obtained from surveys can be used for descriptive purposes or for investigating the relationship between variables. The data was analysed quantitatively using a computer software SPSS (version 16.0) and full fledged structural equation modelling (SEM) software i.e. analysis of moment structures (AMOS) versions 16.0. SEM was employed for this study because SEM is the most effective technique when the study involves multiple constructs, each represented by many measured variables, and these construct are differentiated based on whether they are exogenous or endogenous (Hair et al., 2010).

\subsection{Sampling}

The instruments used in this study were administered to 450 junior secondary students in Katsina state, Nigeria. A total 
of 330 or $73 \%$ of the questionnaires were returned. Out of the questionnaires returned 20 or $6 \%$ were partially filled and hence were excluded prior to data analysis (Creswell, 2010; Sekaran \& Bougie, 2010). Additionally nine out of the 310 retained cases were discovered to be multivariate outliers and consequently, they were removed from the data set.

\subsection{Instrumentation}

In this study, the DL scale inventory was adopted from Hulpia et. al. (2010) and Davis, (2009). It is multi-dimensional, with five dimensions particularly: cooperation of leadership team (COLT), participative decision making (PDCM), principal leadership (PRIN. L), teacher leadership (TC. L) and artifact (ART). The first three dimensions were adopted from Hulpia et al. (2010), while the remaining two were adopted from Davis (2009) respectively. The validity and reliability of the instruments were confirmed by the owners. Some of the items of the scale include: "There is well functioning leadership team in our school", "Leadership is broadly distributed in this school", "The principal provides leadership in improving academic achievement", "Informal school leaders play an important role in the school in improving the performance of their colleagues", and "Teachers in my school discuss strategies and share materials".

The school effectiveness scale was adopted from Oregon County Public Schools (OCPS). The scale is a 36 item instrument with seven dimensions particularly: safe and orderly environment (SOE), climate of high expectation for success (CHES), instructional leadership (INST.L), opportunity to learn and student time to task (OLSTT), clear and focused mission (CFM), frequent monitoring of student progress (FMSP) and home-school relation (HSR). The owner of the scale claimed that its content validity is good as it was constructed by a panel of expert. Some of the items of the scale are: "School conduct, rules, and procedures are taught and constantly implemented in the classroom", "All cultures including my own are treated fairly and with respect in this school", "Teachers have access to variety of resources which assist them in being successful with students' achievement", "The principal is perceived as a coach, partner and cheer leader in the instructional process", "The school mission uses 'learning for all' as the basic premise", and "Parents actively participate in school activities and Teachers feel comfortable communicating with different parents".

The last scale used in this study, organizational commitment questionnaire (OCQ) is adopted from Mowday et al. (1979). It is fifteen (15) item instrument. Six of the items were negatively worded, while the remaining nine items were positively worded. In using the scale, the authors argue that the researcher can either use the 15 item at a go, or use only nine positively worded items. According to Mowday et al. the validity and reliability of either the 15 item or positively nine item are almost the same. It should be noted that the study uses the short version (positively worded items) of Mowday et al. organizational commitment questionnaire. Some of the items read: "I talk up this organization to my friend as a great organization to work for", "I am proud to tell others that I am part of this organization" and "I feel very little loyalty to this organization (R)".

All the instruments used were rated on seven points Likert scale: $1=$ strongly disagree (SD), $2=$ moderately disagree $(M D), 3=$ disagree $(D), 4=$ Neither agree nor disagree $(N), 5=$ agree $(A), 6=$ moderately agree $(M A)$ and $7=$ strongly agree (SA). Table 1 below shows the scales and sub-scales used in the study.

Table 1: Scales and Sub-scales used in the study

\begin{tabular}{|c|c|c|c|c|c|}
\hline Variable (s) & \multicolumn{2}{|c|}{ Type of Variable Sub-Scale } & No.of items & Total & Sources \\
\hline \multirow{5}{*}{$\begin{array}{l}\text { Distributed } \\
\text { Leadership (DL) }\end{array}$} & \multirow[t]{5}{*}{ Exogenous } & Cooperation of the leadership team & 10 & \multirow[t]{5}{*}{31} & \multirow{5}{*}{$\begin{array}{l}\text { Davis, M. W. (2009), } \\
\text { Hulpia, H. (2010). }\end{array}$} \\
\hline & & Participative decision-making & 6 & & \\
\hline & & Artifacts & 4 & & \\
\hline & & Teacher leadership & 6 & & \\
\hline & & Principal leadership & 5 & & \\
\hline School & \multirow[t]{7}{*}{ Endogenous } & Safe and orderly environment & 6 & \multirow[t]{7}{*}{35} & \multirow[t]{7}{*}{ OCPS (n. d) } \\
\hline Effectiveness & & Climate of high expectation for success & 6 & & \\
\hline \multirow[t]{5}{*}{ (SE) } & & Instructional leadership & 4 & & \\
\hline & & Opportunity to learn and student time to task & 3 & & \\
\hline & & Clear and focused mission & 5 & & \\
\hline & & Frequent monitoring of students' progress & 8 & & \\
\hline & & Home school relation & 3 & & \\
\hline $\begin{array}{l}\text { Teacher's } \\
\text { Commitment } \\
\text { (TC) }\end{array}$ & Mediating & Affective Commitment & 15 & 15 & Mowday et al. (1979). \\
\hline Total & 3 & 13 & 81 & 81 & \\
\hline
\end{tabular}




\subsection{Statistical analysis}

The study uses Structural Equation Modeling (SEM), with Maximum Likelihood Estimation (MLE) to analyze the data collected from junior secondary school teachers in Katsina state, Nigeria. The analysis was conducted using Analysis of Moment Structures (AMOS) version 16.0 software. The study uses SEM because, it is more versatile compared to other multivariate methods. Moreover, it is possible with SEM to realize multiple dependant relationship between variables simultaneously (Hoe, 2008). In analyzing the data, full fledge SEM model was specified and the model was assessed using both absolute and comparative fit indices. In all, six fit indices were used particularly: CMIN $\left(X^{2}\right), p$ value, degrees of freedom (DF), CMIN/DF, RMSEA and CFI.

\section{Results}

\subsection{Respondents background}

Table 2 below depicted the background characteristics of the sample of the study. The table showed that 196 or $65 \%$ of the sample were male while 105 equivalent to $35 \%$ were female. On the age of the respondents 120 equivalent to $40 \%$ were within the age bracket of $20-30$ years, 82 or $27 \%$ were $31-40$ years old and 99 or $33 \%$ were 41 years and above. Moreover, the age of the respondents ranged from 20-62 years with an average of 35 years. With regards to working experiences, 91 equivalent to 30\% have 6-10 years working experience, 88 or $29 \%$ have 11 years and above working experience. The working experiences of the respondents ranged from1-35 years with an average of nine years.

Table 2: Respondents Background Characteristics

\begin{tabular}{cccc}
\hline SN & Characteristics & Frequency & Percentage \\
\hline 1 & Gender & & \\
Male & 196 & $65.1 \%$ \\
& Female & 105 & $34.9 \%$ \\
& Total & 301 & $100 \%$ \\
Age & & \\
& $20-30$ & 120 & $39.9 \%$ \\
& $31-40$ & 082 & $27.2 \%$ \\
& $41+$ & 099 & $32.9 \%$ \\
3 & Total & 301 & $100 \%$ \\
& Working Experience & & \\
& $1-5$ & 122 & $40.6 \%$ \\
& $6-10$ & 091 & $30.2 \%$ \\
& $11+$ & 088 & $29.2 \%$ \\
& Total & 301 & $100 \%$ \\
\hline
\end{tabular}

\subsection{Specifying the Measurement Model of the latent constructs.}

Before specifying the Structural Model (SM), we specified the Measurement Model (MM) of the latent variables (DL, SE and TC) of the study. This method is known as two steps Structural Equation Modeling procedure (Hair et al 2010). Additionally, Hair et al. (2010) argue that if the MM is specified and fitted well, fitting the SM will be easier. Figure 2 below shows the specified MM.

The fit indices used to assess the model showed that $\mathrm{CMIN}=336.031, p=.000$ with 149 degrees of freedom. This result indicates that the model failed to fit the sample data as indicated by $p$ value of .000 . However, as argued by scholars, CMIN is always sensitive to sample size, hence, other fit indices need to be examined before concluding on whether the model fit to the data or not. Consequently, by examining CMIN/DF (2.25), CFI (.922) and RMSEA (.065), indicate that the model moderately fit the sample data. Moreover, the CMIN/DF, CFI and RMSEA were all within the minimum threshold value of 3.0, .90 and .08 as recommended by scholars (Hair et al. 2010).

\subsection{Specifying the Structural Model}

Figure 3 below shows the structural model specified in order to test the three hypotheses postulated for this study. The 
model was assessed using fit indices, standardized coefficients, Squared Multiple Correlation (SMC) among others. With regards to fit indices, Table 2 above and Figure 3 below indicate that the specified Structural Model fit the sample data moderately well. The $X^{2}(C M I N)$ value $=336.031$, with $.000 p$ values and 149 degrees of freedom. Assessing the model using $X^{2}$ indicates that the model did not fit the sample data. However, as indicated earlier the $X^{2}$ statistics is highly sensitive to sample size. Besides, other fit indices; CMIN/DF (2.25), CFI (.922) and RMSEA (.065) indicate that the model fit the sample data fairly well, taking into consideration the cutoff point of $\leq 5, \geq .9$, and $\geq .08$ recommended for CMIN/DF, CFI and RMSEA respectively. With regards to factor loadings and SMC the model can also be said to reasonably fit the model data fairly well.

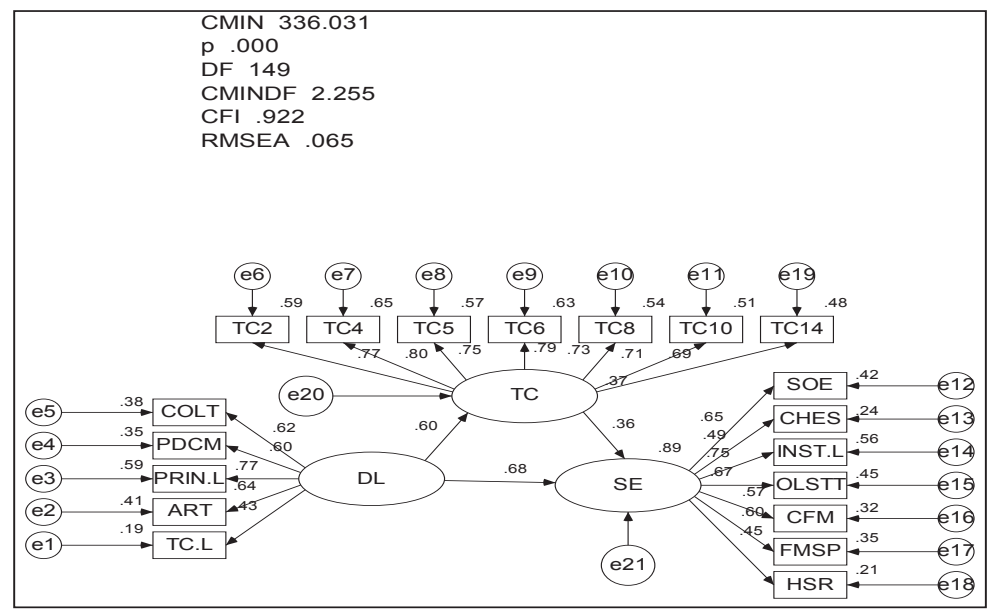

Figure 3: The Specified Structural Model of Study

Table 3 and Figure 3 show that DL influences SE (standardized coefficient .68), TC also influences SE (standardized coefficient .36) and TC mediates the relationship between DL and SE (standardized coefficient .22). This result supports all three hypotheses developed for this study.

Table 3: Summary of supported hypotheses

\begin{tabular}{|c|c|c|c|}
\hline$\overline{\mathrm{SN}}$ & Hypothesis & Decision & Justification \\
\hline 1 & $\begin{array}{l}\text { There is a statistically direct significant relationship between distributed } \\
\text { leadership (DL) and school effectiveness (SE). }\end{array}$ & Supported & Standardized Coefficient (.68) \\
\hline 2 & $\begin{array}{l}\text { There is a statistically direct significant relationship between teachers' } \\
\text { commitment (TC) and school effectiveness (SE). }\end{array}$ & Supported & Standardized Coefficient (.36) \\
\hline 3 & $\begin{array}{l}\text { Teachers' commitment (TC) mediates the relationship between distributed } \\
\text { leadership (DL) and school effectiveness (SE). }\end{array}$ & Supported & Standardized Coefficient (.22) \\
\hline
\end{tabular}

\section{Discussions}

The main objectives of this study are to examines the influence of distributed leadership on school effectiveness among secondary school teachers in Katsina state Nigeria moreover, the study investigates whether teachers commitment mediate the relationship between distributed leadership and school effectiveness.

The study adopted and adapted the relevant survey instruments/questionnaires (as discussed in methodology) to get the required data from the respondents (sample teachers) in the sampled secondary schools in Katsina state. The data collected was analyzed using Special Package for Social Science Research (SPSS) and SEM to establish the relationship between the variables of the study. SEM was employed and used extensively because it is one of the most effective techniques of establishing relationship between endogenous and exogenous variables (Hair et.al. 2010).

The findings as depicted in the specified structural model of the study (Figure 3) above indicate that DL is positively and directly influences SE (standardized coefficient .68). It should be stressed that a standardized path 
coefficient greater that .50 indicates a large effect size (Kline, 2010). This implies that teachers in the sampled schools (Katsina State) believed that leadership is to some extent is being distributed effectively in their respective schools and consequently affect positively how the school is governed effectively. This result also revealed that the sampled schools are to some extent effective compared to those schools where leadership is not being distributed or shared between various levels in the organization. The results of the study supports the finding of Pont et al. (2008) who opined that DL across members will reduce the problems that the schools are facing and consequently enhanced the school effectiveness.

The findings of this study also support the earlier findings by Silins and Mulford (2002) that the more distributed form of leadership is practiced the more it influences student outcomes. Moreover, the results of this study concur with that of Leithwood et al. (2006) who found in Canada that distributing high percentage of leadership activities to teachers at all levels has a positive influence on teachers' effectiveness and students engagement (as cited in Harris 2008b). Additionally Harris (2012: 9) argued that "distributed leadership is increasingly been seen as a contributor to organizational growth and success".

Additionally, the specified structural model as depicted in Figure 3 above indicates that TC positively and directly influence SE. It has been established that staff who are committed both organizationally and professionally tend to perform better than those who are less committed and their behavior improves overall organizational effectiveness (Aranya \& Ferris, 1984). Moreover, the result also supports the findings of Graham (1996), Eginli (2009) and Razak et al. (2009). Conclusively, the findings indicate that TC mediates the relationship between DL and SE. According to Hallinger and Heck (1998) mediated effects gives a concrete indication of possible ways through which leadership may affect school outcomes and effectiveness.

It is worth noting that the findings of this study is equally supporting the Islamic perspective of leadership which always encourages the Islamic leaders to consult their followers widely before taking critical decisions regarding the overall development of the organization. This is due to if the followers were involved in the decision making, they will demonstrate better commitment towards in implementing the decisions, compared to the situation if they were excluded. This is supported by God that (Al Quran: Surah Al- shura: 38) "Those who harken to their Lord and establish regular prayer; who (conduct) their affairs by mutual consultation". Further, Allah says, "And those who answer the Call of their Lord, and to worship none but Him alone, and perform their prayers, and who conduct their affairs by mutual consultation, and who spend of what we have bestowed on them." Quran 42:38. The Islamic Leadership Model and the principles associated with it offer a leadership alternative which can open the door of excellence and achievement.

As for the implications the study brought to the fore the necessity for educational stake holders, especially, educational administrators at the school and ministry level to come up with more avenues of enhancing teachers' commitment and leadership distribution in secondary schools. The educational leaders at school level need to ensure that enhancing teachers commitment should be one of its priorities as far as strategic planning for school is concerned (Fiedler, 1989). The schools' change management process would be in greatest trouble if the teachers' commitment factor is neglected by the management. Developing and improving the process of organizational learning also is somewhat pertinent in regard to teachers' commitment. This will go along way in enhancing junior secondary school effectiveness. Moreover, the study has theoretically contributed to the existing literature, considering the fact that previously, most of the studies conducted on distributed leadership and school effectiveness were conducted in the West and Asian countries, with few or none in the continent of Africa in general and in the Republic of Nigeria in particular. In addition the study managed to propose a model of distributed leadership and school effectiveness, which is a significant theoretical contribution to the existing literature and indigenous body of knowledge.

\section{Conclusion}

Notwithstanding, the above contributions, this study has some limitations. First, the study was conducted in public junior secondary schools, as it does not include private junior secondary schools and senior secondary schools. As such, there is need for caution in generalizing the result to the entire secondary schools in Katsina state, Nigeria. Secondly was time consumption factor. The third reason is the problem of the cooperation from the respondents and participants of the study. They just refused to cooperate in some cases. To ensure that the study get enough respondents, certain steps needed to be taken such as giving a token of appreciation to the participants. As for generalization, more studies need to be to be conducted in senior secondary schools as well as junior and senior private secondary schools in future. 


\section{References}

Ali, A. Y. (1980). The meaning of the Holy Quran. USA, Amana corporation, Brentwood, Maryland.

Angelle, P. S. (2010). An organizational perspective of distributed leadership: A portrait of a middle school. ProQuest Education Journals, 33(5), 1-16.

Aranya, N., \& Ferris, K. R. (1984). A re-examination of accountants' organizational-proffessional conflict. The Accounting Journal Review, 59, 1-15.

Bailey, C. (2013, September 2). Why every great leader is also a great follower [Web log message]. Retrieved from http://danblackon leadership.info/archives/3997

Bennett, N., Harvey, J., \& Woods, P. (2003). Desk study of distributed leadership, NCSL/CEPAM, Nottingham.

Blasé, J.R. \& Blasé, J. (1999). Implementation of shared governance for instructional improvement: principals' perspectives, Journal of Educational Administration, 37,5, 476-500.

Bogler R. \& Somech A. (2004). Influence of Teacher Empowerment on Teachers Organizational Commitment, Professional Commitment and Organizational Citizenship Behavior in Schools. Teaching and Teacher Education 20, 277-289.

Burke, C.S., Fiore, S.M. \& Salas, E. (2003). The role of shared cognition in enabling shared leadership and team adaptability, in Pearce, C.J. \& Cogner, J.A. (Eds.), Shared Leadership: Reframing the How and Ways of Leadership, Sage, Thousand Oaks, CA, pp. 103-122.

Camburn, E., Rowan, B. \& Taylor, J.E. (2003). Distributed leadership in schools: the case of elementary schools adopting comprehensive school reform models, Educational Evaluation and Policy Analysis, 25,4,347-373.

Creswell, J. W. (2010). Educational Research: Planning, Conducting, and Evaluating Quantitative and Qualitative Research, New jersey, Pearson Prentice Hall.

Daft, L.R. (1999). Leadership: theory and practice, U.S.A., The Dryden press.

Davis, M. W. (2009). Distributed Leadership and School Performance. Unpublished Ph.D Thesis, George Washington University USA.

Eginli, I (2009). Principal Leadership and Teacher Commitment to the Proffession: The Mediating role of Collective Efficacy and Teacher Efficacy. Unpublished Ph.D Thesis, George Mason University, Fairfax V.A.

Fidler, B. (1989). Effective local management of schools: a strategic approach, Harlow, UK: Longman

Fletcher, J.K. \& Kaufer, K. (2003). Shared leadership paradox and possibility, in Pearce, C.J. \& Conger, C. (Eds.), Shared Leadership: Reframing the How and Whys of Leadership, Sage, Thousand Oaks, CA, pp. 21-47.

Fullan, M. (2007). Turnaround leadership, Jossey-Bass, San Francisco, CA.

Fullan, M. (2001). Leading in a culture of change, Jossey-Bass, San Fransisco, CA.

Graham, K.C. (1996). Running ahead Enhancing Teacher Commitment, JOPERD, 67(1), 45-47.

Gronn, P. (2002a). Distributed leadership as a unit of analysis, The Leadership Quarterly, 13,423-451.

Gronn, P.(1999). Substituting for leadership: the neglected role of the leadership couple, The Leadership Quarterly, 10, 1, 41-62.

Gronn, P.(2000). Distributed properties: a new architecture for leadership, Educational Management and Administration, 28, 3, $317-338$.

Gronn, P.(2002b). Distributed leadership, in Leithwood, K. and Hallinger, P. (Eds.), Second International Handbook of Educational Leadership and Administration, Kluwer Acadmic Publishers, Dordrecht, pp. 653-696.

Gronn,P. (2008). The future of distributed leadership, Journal of Educational Administration, 46,2, 141-158.

Hargreaves, A. \& Fink, D. (2008). Distributed leadership: democracy or delivery? Journal of Educational Administration, 46, 2, $229-240$.

Hair, J. F., Black, C. W., Babin, B. J. \& Anderson, R. E. (2010). Multivariate Data Analysis: A Global Perspective, New York, Pearson Prentice Hall.

Hallinger, P. \& Heck, R. H. (1998). Exploring the principal's contribution to school effectiveness: 1980-1995, Journal of school effectiveness and school improvement, 9(2), 157-191.

Hallinger, P. (2011). Leadership for learning: lessons from 40 years of empirical research, Journal of Educational Administration, 49,2,

Hallinger, P. \& Heck, R. (1998). Exploring the principal's contribution to school effectiveness 1980-1995, School Effectiveness and School Improvement, 9,2,157-191.

Hallinger, P. \& Heck, R. (1996). Reassessing the principal's role in school effectiveness: a review of empirical research 1980-1996, Educational Administration Quarterly, 32, 1, 5-44.

Hallinger, P. \& Heck, R. (2010). Collaborative leadership and school improvement: understanding the impact on school capacity and student learning, School Leadership and Management, 30, 2, 95-110.

Harris, A. (2005). Crossing boundaries and breaking barriers: distributing leadership in schools, Specialist School Trust, London, available at: www.sst.inet.net.

Harris, A. (2008a). Distributed School Leadership, Developing Tomorrow's Leaders, London, Routledge.

Harris, A. (2008b). Distributed leadership: according to the evidence. Journal of Educational Administration, 46(2). 172.

Harris, A. (2012). Distributed Leadership: Implication for the role of the principal. Journal of Mangement Development, 33(1), 7-17.

Harris, A., Day, C., Hadfield, M., Hopkins, D., Hargreaves, A. \& Chapman, C. (2005). Effective Leadership for School Improvement, Canada, Routledge Falmer.

Harris, A., Leithwood, K., Day, C., Sammons, P. \& Hopkins, D. (2007). Distributed leadership and organizational change: Reviewing the evidence, Journal of educational change, 8, 337-347.

Harris, A. \& Mujis, D. (2004). Improving schools through teacher leadership, Open University Press, London.

Hartely, D. (2007). The emergence of distributed leadership in education: why now?, British Journal of Educational Studies, 55,2,202- 
214.

Heck, R., Larsen, T. \& Marcoulides, G. (1990). Instructional leadership and school achievement: validation of causal model, Educational Administration Quarterly, 26,2,94-125.

Heck, R. H., \& Hallinger, P. (2009). Assessing the Contribution of Distributed Leadership to School Improvement and Growth in Math Achievement. American Educational Research Journal. 46(3), 659-689.

Hoe. S. L. (2008). Issues and procedures in adopting Structural equation modeling technique. Journal of Applied Quantitative Methods, $3(1)$.

Huber, S.G. \& Mujis, D. (2010). New direction for school effectiveness: The growing insight in the importance of school leadership for the quality and development of schools and their pupils. In Huber S.G. (Ed.) School leadership internal perspective studies in educational leadership.

Hutchinson, S. R. (2004). Survey Research. In deMarrais, K \& Lapan, S. D (Ed). Foundations for Research Methods of inquiry in education and social sciences. London, Lawrence Erlbaum Associates, Publishers.

Hulpia, H., Devos, G. \& Keer, H. V. (2010). The influence of Distributed leadership on Teachers' Organizational Commitment: A Multilevel Approach. Journal of Educational Research. Vol. 103, 40-52.

lles, P. \& Feng, Y. (2011). Distributed leadership, knowledge and information management and team performance in Chnese and Western Groups. Journal of Technology Management in China, 6,1, 26-42.

Kelly, R.E. (1992). The power of followership, New York: Doubleday.

Kline, R. B (2010). Principles and Practice of Structural Equation Modeling, London, The Guilford Press.

Leithwood, K., Louis, K.S., Anderson, S. \& Wahlstron, K. (2004). How leadership influences students learning. Retrieved from www.wallacefoundation.org, on $29^{\text {th }}$ July, 2010.

Leithwood, K., Day, C., Sammons, P., Harris, A. \& Hopkins, D. (2006a). Successful school leadership: what it is and how it influences pupil learning, NCSL/Dept for Education \& Skills, University of Nottingham Paul, Nottingham.

Leithwood, K., Day, C., Sammons, P., Harris, A. \& Hopkins, D. (2006b). Seven strong claims about successful leadership, DFES, London.

Leithwood,K., Day, C., Sammons, P., Harris, A. \& Hopkins, D. (2007). Leadership and student learning outcomes, Interim Report, DCSF, London.

Lok, P. \& Crawford, J. (2004). The effect of Organizational culture and Leadership style on Job satisfaction and Organizational Commitment. A cross national comparison, Journal of Management Development, 23(4), 321- 338.

Lunenburg, F. C. (1995). The Principalship: Concepts and Applications USA, Prentice Hall, Inc.

Manz, C.E. \& Sims, H.P. Jr. (1993). Self management as a substitute for leadership: a social learning perspective, Academy of Management Review, 5,3,361-367.

Manz, C.E. \& Sims, H.P. Jr. (1990). Super leadership: leading others to land themselves, Berkeley, New York, NY.

Manz, C.E. \& Sims, H.P. Jr. (1991). Super leading: beyond the myth of heroic leadership, Organizational Dynamics, 22, 18-35.

Mascall, B., Leithwood, K., Straus, T. \& Sacks R. (2008). The relationship between distributed leadership and teachers academic optimism, Journal of educational administration, 46(2). 214-228.

McMillan J.H (1992), Research in Education, a Conceptual Introduction, U.S.A., Harper Collins Publishers.

Megginson, L. C., Mosley, D. C., \& Pietri P. H. (1983). Management: Concepts and Applications, New York, Harper and Row Publishers. Meyer, J. and Allen, N. (1991). The three component of commitment. Human Resource Management Review.

Moos, L., Krejsler, J., Kofod, K.K. \& Jensen B.B. (2005). Successful school Principalship in Danish Schools, Journal of Educational Administration, 43(6).

Mowday, R. T. \& Steers R. M. \& Porter, L. W. (1979). The Measurement of Organizational Commitment. Journal of Vocational Behavior, $14,224-247$.

Mujis, D. (2006). New direction for educational leadership research: towards school effectiveness without schools, Journal of educational change, 7, 141-160.

Mujis, D. \& Harris, A. (2003). Teacher leadership improvement through empowerment? An overview of research, Educational Management, Administration and Leadership, 31, 4, 437-448.

Mujis, D. (2011). Leadership and organizational performance: from research to prescription? International Journal of Educational Management, 25,1,45-60.

Neimann, R. \& Kotze, T. (2006). The relationship between leadership practices and organizational culture: An educational management perspective, South African Journal of Education, 26(4).

Oduro, G. K. T. (2004). Distributed leadership in Schools: What English head teachers say about the 'pull' and 'push' factors, paper presented at the British Educational Research Association Annual Conference, University of Manchester, 16-18 September.

Oregon County Public Schools (OCPS) (n.d). School Effectiveness Survey. Retrieved from:https://www.ocps.net/cs/services/ accountability/improvement/pages/SIProcess.aspx, on 12 ${ }^{\text {th }}$ February, 2011.

Pont, B., Nusche, D. \& Moormen, H. (2008). Improving School Leadership Volume 1: Policy and Practice, Organization for economic cooperation and development (OECD) Retrieved on June 11, 2011 from www.oecd.org/publishing/corrigends. prescription? International Journal of Educational Management, 25(1).

Portin, B.S. (1998). Compounding roles: a study of Washington's principals, International Journal of Educational Research, 29, 4, 381391.

Razak, N. A., Darmawan, I.G.N. \& Keeves, P.J. (2009). Teacher commitment, In Saha, L.J. \& Dworkin A.G. (Eds.) International 
Handbook of Research on teachers and teaching, Springer science, p. 343- 360).

Robinson, V.M.J. (2008). Fit for Purpose: An Educationally Relevant Account of Distributed Leadership, Distributed Leadership: What we know? Journal Of Educational Administration, 46(2).

Robinson, Vivine M.J. (2008). Forging the links between distributed leadership and educational outcomes. Journal of Educational Administration, 46, 2, 241-156.

Ross, L., Rix, M. \& Gold, J. (2005). Learning Distributed Leadership: Part 1, Industrial and Commercial Training, 37 (3).

Salfi, N.A. (2011). Successful Leadership Practices of Head Teachers for School Improvement: Some Evidence from Pakistan. Journal of Educational Administration 49(4).

Scheerens, J. (2000). Improving school effectiveness; Fundamentals of educational planning; Vol. 68, retrieved from http// www.unesco. org//iiep, on $8^{\text {th }}$ December 2010.

Sekaran, U \& Bougie, R (2010). Research Methods for Business: A skill building approach. United Kingdom, John Willey \& Sons Ltd.

Sezgin, F. (2009). Relationship between teacher organizational commitment Psychological hardiness and some demographic variables in Turkish Primary Schools, Journal of educational Administration, 47(5), 630- 651.

Silins, H. \& Mulford, W. (2002). Leadership and School Results. Dordretcht, the Nertherland. Kluwer.

Southworth, G. \& Doughty, J. (2006). A fine British blend, Educational Leadership, May, 51-54.

Suliman, A. M. T. (2002). Is it really a mediating construct? The mediating role of organizational commitment on work climateperformance relationship. Journal of Management Development, 21(3), 170-183.

Spillane, J., Halverson, R. \& Diamond, J. (2001). Towards a theory of leadership practice: a distributed perspective, working article, Northwestern University, Institute for Policy Research, Evanston, IL.

Spillane, J. P. (2006). Distributed leadership, San Francisco, Jossey-Bass.

Storey, A. (2004). The problems of Distributed Leadership in Schools. School Leadership and Management, 24(3).

Teddlie, C. \& Reynolds, D. (Eds) (2000). The international handbook of school effectiveness research, Falmer Press, London.

Wiener, Y. \& Verdi, Y. (1980). Relationships between Job, Organization, and Career Commitment and Work Outcomes-An Integrative Approach, Journal of Organizational Behaviour and Human Performance, 26, 81-96.

Yukl, G. (2002). Leadership in Organization. Upper Saddle River, New Jersey, Prentice Hall Publishing. 